\title{
МЕТОДИКА ОРГАНІЗАЦІЇ САМОСТІЙНОЇ РОБОТИ СТУДЕНТІВ НА ПРИКЛАДІ ДИСЦИПЛІНИ «МЕДИЧНА ТА БІОЛОГІЧНА ФІЗИКА» 3 ОГЛЯДУ НА МОЖЛИВОСТІ СИСТЕМИ ДИСТАНЦІЙНОГО НАВЧАННЯ EDX.ORG
}

\author{
O. E. Prokopchenko, H. M. Lukina, O. Z. Ivanchenko, O. Z. Melnikova, \\ O. V. Prykhodko \\ Zaporizhzhia State Medical University, Zaporizhzhia

\section{METHODOLOGY OF ORGANIZATION OF THE INDEPENDENT WORK OF STUDENTS USING AN EXAMPLE OF DISCIPLINE “MEDICAL AND BIOLOGICAL PHYSICS” BASED ON POSSIBILITIES OF DISTANCE EDUCATIONAL SYSTEM EDX.ORG}

\begin{abstract}
Анотація. У статті визначено потенційні можливості платформи дистанційного навчання Edx.org для організації і проведення самостійної роботи студентів при вивченні дисципліни «Медична та біологічна фізика» за напрямком підготовки магістра за спеціальністю «Лікувальна справа» (англомовна форма навчання).

Представлено результати порівняльного аналізу і виявлено спільні елементи навчальної програми з медичної та біологічної фізики й дистанційного курсу «Fundamentals of Neuroscience». Навчально-методичні матеріали від Еdх.org ми розглядали як складову частину домашньої підготовки й основу для самостійної та аудиторної роботи студентів. Наведено приклад організації самостійної роботи студентів з використанням можливостей системи дистанційного навчання Edx.org. Легальне запозичення і використання окремих навчальних матеріалів для дистанційного навчання дозволяють актуалізувати, стандартизувати й оптимізувати роботу студентів при проведенні самостійної та індивідуальної роботи при вивченні дисципліни «Медична та біологічна фізика».

На основі проведеного аудиту курсу «Neuroscience» запропоновано використовувати організаційну структуру курсу з метою організації самостійної та аудиторної роботи студентів з дисципліни «Медична та біологічна фізика».

Ключові слова: медична і біологічна фізика; самостійна робота студентів; методи дистанційного навчання; інформаційні технології навчання.

Abstract. The article adduces the potential possibilities of distant education Edx.org platform for organization and realization of individual work of students in the process of study of "Medical and Biological Physics" to master degree in "General Medicine” (for English speaking students).

The results of the comparative analysis are presented and common elements of the curriculum in Medical and Biological Physics and distance course "Fundamentals of Neuroscience" are revealed. We considered Edx.org educational materials as an integral part of home training and a basis for students' independent and classroom work. An example of organizing students' independent work using the capabilities of the Edx.org distance learning system is given. Legal borrowing and the use of separate educational materials for distance learning make it possible to actualize, standardize and optimize the work of students in independent and individual work in the study of the discipline "Medical and Biological Physics".
\end{abstract}

() О. Є. Прокопченко, Г. М. Лукіна, О. З. Іванченко та ін. 
On the basis of the conducted audit of the course "Neuroscience" it is proposed to use the organizational structure of the course in order to organize the independent and auditor work of students in the discipline "Medical and Biological Physics".

Key words: medical and biological physics; individual work of students; methods of distance learning; information technologies of training.

Вступ. Відповідно до стандартів і рекомендацій щодо забезпечення якості навчання, самостійна та індивідуальна робота студентів розглядається як складовий елемент навчально-методичного комплексу з дисциплін фахової підготовки студентів [2, $4,5]$. Самостійна робота є основою дистанційного навчання та підгрунтям для індивідуального, мотивованого навчання та формування професійної компетенції [1, 3]. 3 іншої сторони, дистанційні методи $€$ мотиваційними по відношенню до класичних форм навчання і такими, що сприяють оптимізації та підвищенню ефективності аудиторного процесу підготовки. Порівняння курсу «Neuroscience», розміщеного на платформі дистанційного навчання Edx.org, з навчальною програмою та змістом дисципліни «Медична та біологічна фізика» $є$ актуальним і корисним з огляду на вдосконалення та оптимізацію навчального процесу на рівні відповідності вимог, змістовності, методів представлення навчальних матеріалів, визначення рівня складності і стандартизації тестових запитань, що в подальшому є підгрунтям для ліцензійного іспиту «Крок 1». Загальний огляд курсу «Neuroscience» має мотиваційний характер як за рахунок визначення актуальності в системі міжнародної підготовки та освітніх стандартів від Гарварду, так і за рахунок міждисциплінарних зв'язків.

Мета дослідження. На основі порівняльного аналізу та за результатами аудиту курсу «Fundamentals of Neuroscience» (Edx.org) визначити можливості платформи дистанційного навчання для організації і проведення самостійної роботи студентів при вивченні дисципліни «Медична та біологічна фізика» за напрямком підготовки магістра за спеціальністю «Лікувальна справа» (англомовна форма навчання). Визначити методи організації індивідуальної роботи студентів на основі міжнародних освітніх стандартів та запозичення й адаптації навчальних матеріалів; виявити можливості впровадження дистанційного курсу як складового елементу процесу навчання.

Методи дослідження: порівняльний аналіз та аудит контенту, метод педагогічного експерименту.

Результати дослідження. На прикладі курсу «Fundamentals of Neuroscience» проведено аудит змісту та порівняльний аналіз відповідних програмних вимог; визначено за актуальністю ключові моменти курсу в порівнянні з методикою викладання «Медичної та біологічної фізики». Об’єктом для розгляду обрана тема «Basic physics of Electric Membrane Potentials. Resting Membrane Potential \& Action Potential» в порівнянні 3 «Fundamentals of Neuroscience, Part 1: The Electrical Properties of the Neuron». Програма курсу містить такі розділи: The Resting Potential; Passive Membrane Properties; Action Potentials; Action Potential Propagation; DIY Labs. За основу організації самостійної роботи студентів ми взяли загальну структуру дистанційного курсу. Курс «Fundamentals of Neuroscience» структурно організований у вигляді чотирьох частин уроків, кожен із яких містить стандартні навчальні (текстові, аудіовізуальні, інтерактивні) та контролюючі елементи (тестові запитання із зворотним зв'язком), що спрямовані на індивідуальну роботу користувачів із наданою можливістю дистанційного обговорення навчального матеріалу (елемент зворотного зв'язку). Загальні навчально-методичні матеріали, в тому числі відеоматеріали або відеолекції, дозволяють викладачам курсу та студентам англомовної форми навчання «відчути» і визначити рівень викладення навчального матеріалу за міжнародними стандартами. Ми використовуємо і пропонуємо так званий метод запозичення. Запозичення ми трактуємо як більше, ніж сліпе копіювання. Скоріше, це є метод перенесення, адаптації, порівняння та оптимізації, звичайно, разом із збереженням авторських прав. Відомо, що підготувати якісні навчальні візуальні або інтерактивні матеріали вкрай складно та неефективно, з огляду на факт їх існування. Зазначимо також, що відеоматеріали курсу можуть бути легально завантажені і мають текстовий супровід (субтитри) та підходять для використання як матеріали для подальшого обговорення (дискусії), складання тестових запитань, перевірки домашньої підготовки. Для окремих випадків є лабораторні завдання за типом DYI - Do It Yourself Labs. Так, пропонується виконання лабораторних завдань, назва яких говорить сама за себе: Recording and Stimulating a Nerve; Rate Coding; Electrode Referencing; Neuropharmacology; The Electromyograph; Grasshopper Vision. Виконання кожної із лабораторних робіт супроводжується відповідними відеоінструкціями із субтитрами. Відео пояснюють апаратну базу, наприклад, роль електро- 
дів, роботу електроміографа; значення розчинів та речовин, що блокують біохімічні процеси (в частині Neuropharmacology) тощо. Метою цих відео $€$, напевно, залучення студентів до активної участі в експериментах або їх обговоренні і спонукають до отримання результатів. Останнє формує результативне навчання. Можливим $є$ подальший розгляд результатів віртуальних експериментів он-лайн (discussion board). Тому ми приймаємо їх як базові при аналізуванні експериментальних результатів та формуванні тестових контролюючих запитань.

Фінальний тест з курсу представлено запитаннями для кожного заняття - питання за типом MCQ, True/False i у формі задач, у тому числі із графічно та інтерактивно представленою умовою. Більшість запитань за змістом та рівнем складності збігається із відповідними питаннями з курсу медичної та біологічної фізики. Окремі запитання прямо пов'язані із фізикою - електроємність, потік, струм, проникність, електрична напруга, електричний потенціал та одиниці вимірювання. Окремі тестові запитання «Neuroscience» спираються на інтерактивні завдання за типом: «Що відбудеться, якщо...» Тому актуальним $є$ застосування інтерактивних методів навчання на різних рівнях. Зауважимо, можливість залучення та участь в експериментах на платформі Edx.org, що мають ознаки віртуальних та пов'язані із супровідним сайтом https://backyardbrains.com/ experiments/, є актуальними для українських студентів з огляду на аудіювання англомовних навчальних матеріалів при підготовці проходження ліцензійних іспитів.

Навчальні матеріали курсу в цілому можуть розглядатися як такі, що є: надлишковими, але мотиваційними або такими, що здатні зацікавити студента; такими, що повністю збігаються за змістом із програмою медичної фізики та біофізики; інноваційними в сенсі використання інтерактивного супроводу.

Таким чином, у результаті порівняння виявлено частковий або повний збіг матеріалів 3 «Neuroscience» 3 навчальними питаннями «Mедичної та біологічної фізики». Спостерігається повний збіг за темою, в цілому або за змістом. Збіг може бути частковим або повним, або надлишковим. В останньому випадку є можливість вибору навчального матеріалу з метою його корегування та адаптації. Вказане $є$ рекомендованим для застосування при формуванні плану самостійної роботи студентів. Матеріали курсу «Fundamentals of Neuroscience» застосовані нами в якості: елементу підготовки домашнього завдання; задля індивіду- ального самостійного опрацювання; матеріалу для підготовки до проходження тестування; виконання практичних та експериментальних завдань. Поміж іншого, матеріали першої частини «Neuroscience» рекомендується застосовувати для підготовки есе (assay); в якості елементу, що формують міждисциплінарні та міжпредметні зв’язки.

Впровадження матеріалів «Fundamentals of Neuroscience» сприяє також розширенню світогляду, формуванню аналітичного мислення, навичок застосування методів порівняльного аналізу і, в цілому, сприяє актуалізації та мотивації. На останнє ще раз звернемо увагу. Вплив «Гарварду», за нашими спостереженнями, є дійсно важливим. Підготовка і проходження навчання на рівні та відповідно до навчально-методичних матеріалів, вимог і міжнародних стандартів Гарвардського університету є мотиваційними та інтегруючими. Крім того, $\epsilon$ можливість отримання сертифіката зазначеного дистанційного курсу. Інтеграція методів організації самостійної роботи студентів з елементами платформи дистанційного навчання Edx. org та поширення на ії основі ідеї дистанційного навчання може стати оптимальним та ефективним для сучасного процесу навчання.

Висновки та перспективи подальших досліджень. На основі проведеного аудиту курсу «Neuroscience» (Edx.org, Гарвардський університет) запропоновано використовувати методику та організаційну структуру курсу з метою організації самостійної й аудиторної роботи студентів 3 дисципліни «Медична та біологічна фізика». Запозичення окремих навчальних матеріалів для дистанційного навчання дозволяє актуалізувати й оптимізувати роботу студентів при проведенні самостійної та індивідуальної роботи при вивченні дисципліни «Медична та біологічна фізика». Виявлені спільні елементи навчальної програми дисципліни та дистанційного курсу «Fundamentals of Neuroscience» сприяють мотивованому підходу і впровадженню міжнародних освітніх стандартів. Навчально-методичні матеріали від Edx.org ми розглядали як частину домашньої підготовки й основу для самостійної та аудиторної роботи студентів. Рівень «запозичення» навчального контенту визначається індивідуальною мотивацією студента та викладача, що виступає в ролі модератора курсу й організатора самостійної, індивідуальної роботи. Можливим і рекомендованим нами є запозичення задля ознайомлення в цілому; ознайомлення з метою порівняння і визначення актуальності та міжпредметних зв' язків; з метою вдосконалення ви- 
кладення окремих тем або навчальних питань та використання навчальних матеріалів, які оптимізують навчання. Вважаємо представлений у статті підхід актуальним при вивченні медичної та біологічної фізики незалежно від форми і мови навчання.

В якості перспективи щодо представленого дослідження заплановано вдосконалення робочої програми $з$ дисципліни «Медична та біологічна

\section{Список літератури}

1. Петрук В. А. Теоретико-методичні засади формування професійної компетентності майбутніх фахівців технічних спеціальностей у процесі вивчення фундаментальних дисциплін : монографія / В. А. Петрук. Вінниця : УНІВЕРСУМ, 2006. - 292 с.

2. Положення про організацію навчального процесу у вищих навчальних закладах України від 02.06.93 № 161 // Збірник нормативних актів України щодо організації навчально-виховного процесу у вищому навчальному закладі. - К. : УАЗТ, 2003. - 410 с.

3. Прокопченко О. Є. Окремі методи організації самостійної роботи студентів при вивченні вищої математики і статистики за напрямком підготовки «Фармація, промислова фармація» / О. Є. Прокопченко, Г. М. Лукіна, Г. Р. Мікаєлян // Сучасні підходи до вищої медичної осві-

\section{References}

1. Petruk, V.A. (2006). Teoretyko-metodychni zasady formuvannia profesiinoi kompetentnosti maibutnikh fakhivtsiv tekhnichnykh spetsialnostei u protsesi vyvchennia fundamentalnykh dystsyplin: Monohrafiia [Theoretical and methodical principles of formation of professional competence of technical specialties in the process of studying fundamental disciplines: Monograph]. Vinnytsia “UNIVERSUM” [in Ukrainian].

2. Polozhennia pro orhanizatsiiu navchalnoho protsesu u vyshchykh navchalnykh zakladakh Ukrainy vid 02.06.93 №161 [Regulations on the organization of the educational process in higher educational institutions of Ukraine]. Zbirnyk normatyvnykh aktiv Ukrainy shchodo orhanizatsii navchalno-vykhovnoho protsesu u vyshchomu navchalnomu zakladi - Collection of Normative Acts of Ukraine concerning the Organization of Educational Process in a university [in Ukrainian].

3. Prokopchenko, O.Y., Lukina, H.M., Mikaielian, H.R. (2018). Okremi metody orhanizatsii samostiinoi roboty studentiv pry vyvchenni vyshchoi matematyky i statystyky za napriamkom pidhotovky "Farmatsiia, promyslova farmatsiia" [Separate methods of organization of independent work of students in the study of advance mathematics and фізика» в частині мотивації студентів; визначення компетентностей, що базовані на дисциплінах природничого циклу і розширення міждисциплінарних зв’ язків; створення дистанційного курсу на базі локалізованої університетської версії Edx. org; представлення методики формування бази аудіовідео та інтерактивних (симуляційних) навчальних матеріалів.

ти в Україні : матеріали XV Всеукр. наук.-практ. конф. 3 міжнар. участю (Тернопіль, 18-19 трав. 2018 р.) : у 2 т. / Терноп. держ. мед. ун-т ім. І. Я. Горбачевського. - Тернопіль : ТДМУ, 2018. - Т. 2. - С. 245.

4. Стандарти і рекомендації щодо забезпечення якості в Європейському просторі вищої освіти (ESG). - K. : ТОВ «ЦС», 2015. - 32 с.

5. Черних В. П. Компетентнісний підхід у створенні стандарту вищої освіти спеціальності «Фармація» / В. П. Черних, А. А. Котвіцька, С. В. Огарь // Медична освіта. - 2016. - № 2. - С. 107-109.

6. David Cox. Fundamentals of Neuroscience, Part 1: The Electrical Properties of the Neuron / David Cox. Access mode : https://courses.edx.org/courses/coursev1:HarvardX+MCB80.1x+3T2018/course/.

statistics for the field of study "Pharmacy, Industrial Pharmacy”]. Materialy XV Vseukr. nauk.-prakt. konf. z mizhnar. uchastiu "Suchasni pidkhody do vyshchoi medychnoi osvity v Ukraini" - Modern Approaches to Higher Medical Education in Ukraine: Materials XV All-Ukrainian. Research Practice Conf. with international participation. (May, 1819). Ternopil State Medical University. Ternopil: TDMU [in Ukrainian].

4. Standarty i rekomendatsii shchodo zabezpechennia yakosti v Yevropeiskomu prostori vyshchoi osvity (ESG) [The Standards and guidelines for quality assurance in the European Higher Education Area (ESG)]. Kyiv: TOV “TSS" [in Ukrainian].

5. Chernykh, V.P., Kotvitska, A.A., \& Ohar, S.V. (2016). Kompetentnisnyi pidkhid u stvorenni standartu vyshchoi osvity spetsialnosti "farmatsiia” [Competency approach in creation of the standard of higher education specialty "pharmacy”]. Medychna osvita - Medical Education, 2, 107-109 [in Ukrainian].

6. David Cox. Fundamentals of Neuroscience, Part 1: The Electrical Properties of the Neuron. Retrieved from: https://courses.edx.org/courses/course-v1:HarvardX+ MCB80.1x+3T2018/course/. 